\title{
APLIKASI KLASIFIKASI ALGORITMA C4.5 (STUDI KASUS MASA STUDI MAHASISWA FAKULTAS MATEMATIKA DAN ILMU PENGETAHUAN ALAM UNIVERSITAS MULAWARMAN ANGKATAN 2008)
}

\author{
Miftahul Chair ${ }^{1)}$, Yuki Novia Nasution ${ }^{2)}$, Nanda Arista Rizki ${ }^{3)}$ \\ 1,2,3) Program Studi Statistika, FMIPA, Universitas Mulawarman \\ Jl. Barong Tongkok No. 5 Kampus Unmul Gn. Kelua Sempaja Samarinda 75119 \\ E-Mail : : iifkhair@yahoo.com ${ }^{1)}$; yuki.novia.n@gmail.com ${ }^{2)}$; nanda.arista.r@gmail.com ${ }^{3)}$
}

\begin{abstract}
ABSTRAK
Klasifikasi merupakan pengelompokkan sampel berdasarkan ciri-ciri persamaan dan perbedaan dengan menggunakan variabel target sebagai kategori. Pohon Keputusan adalah pohon klasifikasi yang digunakan sebagai prosedur penalaran untuk mendapatkan jawaban dari masalah yang dimasukkan. Penelitian ini membahas tentang pohon keputusan yang dibentuk menggunakan Algoritma C4.5 untuk mengklasifikasi masa studi mahasiswa FMIPA UNMUL angkatan 2008. Algoritma C4.5 merupakan pohon klasifikasi non biner di mana cabang pohon bisa lebih dari dua. Dalam Algoritma C4.5, pohon keputusan dibentuk berdasarkan kriteria entropy. Berdasarkan hasil penelitian dalam klasifikasi masa studi mahasiswa FMIPA UNMUL angkatan 2008 (102 data) diperoleh 16 aturan yang terbentuk. Dari hasil klasifikasi yang telah dilakukan diperoleh ketepatan akurasi untuk data training (75 data) adalah $100 \%$ dan untuk data testing (27 data) adalah 72,4 \%.
\end{abstract}

Kata Kunci : algoritma C4.5, entropy, klasifikasi, masa studi, pohon keputusan

\section{PENDAhuluan}

Data mining adalah proses yang menggunakan teknik statistik, matematika, kecerdasan buatan, dan machine learning untuk menguraikan, mengidentifikasi informasi yang bermanfaat, dan pengetahuan yang terakit dari berbagai database besar [3].

Klasifikasi merupakan pengelompokkan sampel berdasarkan ciri-ciri persamaan dan perbedaan dengan menggunakan variabel target sebagai kategori. Ada beberapa macam pengklasifikasian dalam data mining yaitu decision tree, naive Bayes, svm, dan lain-lain [5].

Decision tree (pohon keputusan) adalah pohon klasifikasi yang digunakan sebagai prosedur penalaran untuk mendapatkan jawaban dari masalah yang dikasuskan. Dalam decision tree, daerah pengambilan keputusan yang sebelumnya kompleks dapat diubah menjadi lebih sederhana. Banyak algoritma yang dapat dipakai dalam pembentukan decision tree yaitu ID3, CART, C4.5, dan lain-lain. Algoritma adalah urutan langkah-langkah yang logis untuk menyelesaikan suatu masalah [6].

Algoritma ID3 (Iterative Dichotomiser 3) pertama kali diperkenalkan oleh Quinlan pada Tahun 1986 yang digunakan untuk menginduksi decision tree. Algoritma ID3 dapat bekerja baik pada semua fitur yang mempunyai tipe data kategorik (nominal atau ordinal). Namun dalam perkembangannya, Algoritma ID3 mengalami perbaikan menjadi Algoritma C4.5. Perbaikan yang ada pada Algoritma C4.5 adalah dapat menangani fitur dengan tipe numerik (interval atau rasio), melakukan pemotongan (pruning) decision tree, dan penurunan (deriving) rule set [6]. Keunggulan algoritma $\mathrm{C} 4.5$ adalah tingkat akurasi klasifikasi sangat tinggi dibanding metode klasifikasi lain. Salah satu contoh dari pengklasifikasian Algoritma C4.5 yaitu tentang masa studi mahasiswa.

Masa studi adalah salah satu tolak ukur keberhasilan dalam studi seorang mahasiswa. Semakin cepat lama studi mahasiswa dalam menempuh perkuliahan, dapat mengindikasikan bahwa mahasiswa tersebut rajin dan cerdas. Masa studi juga menjadi evaluasi tersendiri bagi suatu universitas terkait kebijakan pendidikan di universitas tersebut. Salah satu kewajiban universitas adalah mengontrol masa studi mahasiswanya diantaranya dengan menentukan batasan masa studi yang ditempuh mahasiswa yaitu paling lama 7 tahun akademik untuk program sarjana dan program diploma 4 atau sarjana terapan berdasarkan Standar Nasional Pendidikan Tinggi Nomor 44 Tahun 2015.

Ada beberapa faktor yang mempengaruhi masa studi mahasiswa yaitu IPK, jenis kelamin, asal daerah, jurusan kuliah, asal sekolah, dan pekerjaan orang tua. Penelitian ini terkait dengan penelitian sebelumnya dengan judul "Aplikasi Classification and Regression Tree (CART) dan Regresi Logistik Ordinal dalam bidang pendidikan dengan studi kasus Predikat Kelulusan Mahasiswa S1 Fakultas Matematika dan Ilmu Pengetahuan Alam Universitas Mulawarman (FMIPA UNMUL)" oleh Nurbianto (2015). Perbedaannya penelitian ini dengan sebelumnya yaitu terletak di 
metode penginduksi pohon keputusan dan studi kasus.

Berdasarkan pengantar di atas, maka Penulis tertarik untuk membuat penelitian ilmiah dengan judul “Aplikasi Klasifikasi Algoritma C4.5 (Studi kasus: Masa Studi Mahasiswa Fakultas Matematika dan Ilmu Pengetahuan Alam Universitas Mulawarman Angkatan 2008)".

\section{TINJAUAN PUSTAKA}

\subsection{Data Mining}

Data mining adalah suatu proses menemukan hubungan yang berarti, pola, dan kecenderungan dengan memeriksa dalam sekumpulan besar data yang tersimpan dalam penyimpanan dengan menggunakan teknik pengenalan pola seperti teknik statistik dan matematika [5].

\subsection{Klasifikasi}

Dalam pengklasifikasian Peneliti mengelompokkan sampel berdasarkan ciri-ciri persamaan dan perbedaan dengan menggunakan variabel target sebagai kategori. Sebagai contoh, penggolongan masa studi dapat dipisahkan dalam dua kategori, yaitu kurang dari sama dengan 5 tahun dan lebih dari 5 tahun. Beberapa metode atau teknik yang digunakan dalam klasifikasi dan estimasi dapat juga digunakan (untuk keadaan yang tepat) untuk memprediksi.

\subsection{Decision Tree}

Decision Tree (Pohon Keputusan) adalah pohon klasifikasi yang digunakan sebagai prosedur penalaran untuk mendapatkan jawaban dari masalah yang dimasukkan. Pohon yang dibentuk tidak selalu berupa pohon biner. Jika semua fitur dalam data menggunakan dua macam nilai kategorik maka bentuk pohon yang didapatkan berupa pohon biner namun jika dalam fitur berisi lebih dari dua macam nilai kategorikal atau menggunakan tipe numerik maka bentuk pohon yang didapatkan biasanya tidak berupa pohon biner [6].

\subsection{Kriteria Entropy}

Kriteria entropy banyak digunakan dalam algoritma ID3, C4.5, dan C5.0 yang didasarkan pada pemilihan titik pemecahan yang memaksimalkan informasi gain (pengurangan entropy maksimal). Nilai minimal nol ketika semua data pada node tersebut dimiliki oleh suatu kelas yang mengimplikasikan paling informatif [6].

Karakteristik dari decision tree, dibentuk sejumlah elemen sebagai berikut [8]:

1. Node, yang menyatakan variabel. Node bisa berupa variabel akar, variabel cabang, dan kelas.

2. Arm, setiap cabang menyatakan nilai hasil pengujian di node bukan daun.

3. Node akar, tidak mempunyai input arm yaitu lengan masukan dan mempunyai nol atau lebih output arm yaitu lengan keluar.
4. Node internal, setiap node yang bukan daun (non terminal) yang mempunyai tepat satu input arm dan dua atau lebih output arm, node ini menyatakan pengujian yang didasarkan pada nilai fitur.

5. Node daun (terminal) adalah node yang mempunyai tepat satu input arm dan tidak mempunyai output arm. Node ini menyatakan label kelas (keputusan).

Banyak algoritma yang dapat dipakai dalam pembentukan pohon keputusan, antara lain ID3, CART, dan C4.5. Algoritma C4.5 merupakan pengembangan dari algoritma ID3 [5].

\subsection{Algoritma $\mathbf{C 4 . 5}$}

Algoritma C4.5 diperkenalkan oleh Quinlan pada Tahun 1996 sebagai versi perbaikan dari ID3. Dalam ID3, induksi Decision tree hanya bisa dilakukan pada fitur bertipe kategorikal (nominal atau ordinal), sedangkan tipe numerik (interval atau rasio) tidak dapat digunakan. Perbaikannya yaitu tidak hanya dapat menangani fitur bertipe kategorikal, tetapi juga dapat menangani fitur dengan tipe numerik, serta juga dapat melakukan pemotongan (pruning) decision tree, dan penurunan (deriving) rule set. Algoritma $\mathrm{C} 4.5$ juga menggunakan kriteria gain dalam menentukan fitur yang menjadi pemecah node pada pohon yang diinduksi.

Secara umum Algoritma C4.5 untuk membangun pohon keputusan adalah sebagai berikut [4]:

1. Pemilihan variabel akar

Untuk memilih variabel sebagai akar, didasarkan pada nilai gain tertinggi dari variabelvariabel yang ada. Berikut adalah cara untuk menghitung nilai gain:

$\operatorname{Gain}(\mathrm{S}, \mathrm{A})=\operatorname{Entropy}(\mathrm{S})-\sum_{\mathrm{i}=2}^{n} \frac{\mathbf{a}_{\mathrm{i}}}{\mathrm{i}} \times \operatorname{Entropy}\left(\mathrm{S}_{\mathrm{i}}\right)$

dengan:

S : Himpunan kasus

$\mathrm{Si} \quad$ : Himpunan kasus pada partisi ke i

A : Variabel

n : Jumlah partisi atribut A

$\left|\mathrm{S}_{\mathrm{i}}\right| \quad$ : Jumlah kasus pada partisi ke i

$|\mathrm{S}| \quad$ : Jumlah kasus dalam $\mathrm{S}$

Sebelum mendapatkan nilai Gain, dicari terlebih dahulu nilai Entropy. Entropy adalah informasi mengenai proporsi pembagian kelas, nilai entropy berkisar mulai dari 0 sampai dengan 1, jika nilai entropy $=0$, maka menandakan jumlah sampel hanya berada di salah satu kelas, sedangkan jika nilai entropy $=1$, maka menandakan jumlah sampel berada di masing-masing kelas dengan jumlah yang sama. Adapun rumus dasar dari perhitungan Entropy adalah sebagai berikut:

$\operatorname{Entropy}(S)=-\sum_{\mathrm{i}=1}^{\mathrm{p}} \mathrm{p}_{\mathrm{i}} \log _{2} \mathrm{p}_{\mathrm{i}}$ 
dengan:

$\begin{array}{ll}\mathrm{S} & \text { : Himpunan Kasus } \\ \mathrm{n} & \text { : Jumlah partisi } \mathrm{S} \\ \mathrm{p}_{\mathrm{i}} & \text { : Proporsi dari } \mathrm{S}_{\mathrm{i}} \text { terhadap } \mathrm{S}\end{array}$

2. Penentuan cabang untuk masing-masing nilai Untuk penentuan cabang sama seperti mencari variabel akar yaitu didasarkan pada nilai gain tertinggi dari variabel-variabel yang ada.

3. Kelas dibagi dalam cabang dan apabila cabang mempunyai dua kelas maka yang dipilih kelas yang terbanyak.

4. Proses diulang untuk masing-masing cabang sampai semua kelas pada cabang memiliki kelasnya masing-masing.

Dalam melakukan perbandingan hasil klasifikasi dan hasil prediksi maka dilakukan perhitungan tingkat akurasi. Untuk mendapatkan tingkat akurasi aplikasi dari hasil prediksi maka digunakan rumus berikut (David. 2014):

Persentase $=\frac{\text { jumlah predifsi Jenar }}{\text { jumiah Data }} \times 100 \%$

Algoritma C4.5 dapat menangani berbagai macam contoh kasus. Salah satu contoh dari pengklasifikasian Algoritma $\mathrm{C} 4.5$ yaitu tentang masa studi mahasiswa.

\subsection{Masa Studi}

Menurut KBBI (Kamus Besar Bahasa Indonesia), istilah sarjana berasal dari bahasa sansekerta, yang merupakan sebuah gelar akademik yang diberikan kepada lulusan program pendidikan strata satu atau undergraduate. Untuk program Strata Satu (S1), persyaratan penyelesaian studi ditetapkan sekurang-kurangnya telah menempuh 144 SKS dan sebanyak-banyaknya 160 SKS, dengan lama masa studi paling lama 7 tahun akademik untuk program sarjana dan program diploma 4 atau sarjana terapan (Standar Nasional Pendidikan Tinggi Nomor 44 Tahun 2015).

\section{HASIL DAN PEMBAHASAN}

\subsection{Analisis Statistika Deskriptif}

Karakteristik yang digambarkan pada analisis deskriptif adalah IPK kelulusan, Jenis Kelamin, Asal Daerah, Program Studi, Asal Sekolah, dan Pekerjaan Orang Tua. Gambar 1. merupakan persentase kelulusan masa studi mahasiswa FMIPA UNMUL.

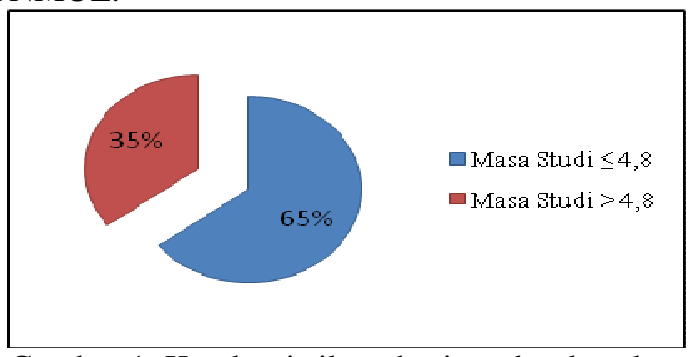

Gambar 1. Karakteristik mahasiswa berdasarkan persentase masa studi
Tabel 1. merupakan tabulasi silang IPK kelulusan dengan masa studi mahasiswa FMIPA UNMUL.

Tabel 1. Tabulasi Silang IPK Lulusan Terhadap Masa Studi

\begin{tabular}{lcccc}
\hline Masa Studi & \multicolumn{3}{c}{ IPK Lulusan $\left(\mathrm{X}_{1}\right)$} & Total \\
& $<3,0($ & $3,00 \leq \mathrm{IPK}<3,50$ & $\geq 3,50$ & \\
\hline Masa Studi $\leq 4,8$ tahu & 0 & 32 & 34 & 66 \\
Masa Studi $>4,8$ tahu & 8 & 19 & 9 & 36 \\
\hline Total & 8 & 51 & 43 & 102 \\
\hline
\end{tabular}

Tabel 2. merupakan tabulasi silang jenis kelamin dengan masa studi mahasiswa FMIPA UNMUL.

Tabel 2. Tabulasi Silang Jenis Kelamin Terhadap Masa Studi

\begin{tabular}{lccc}
\hline Masa Studi & \multicolumn{2}{c}{ Jenis Kelamin $\left(\mathrm{X}_{2}\right)$} & Total \\
& Perempuan & Laki-laki & \\
\hline Masa Studi $\leq 4,8$ tahu: & 45 & 21 & 66 \\
Masa Studi $>4,8$ tahu & 22 & 14 & 36 \\
\hline Total & 67 & 35 & 102 \\
\hline
\end{tabular}

Tabel 3. merupakan tabulasi silang asal daerah dengan masa studi mahasiswa FMIPA UNMUL.

Tabel 3. Tabulasi Silang Asal Daerah Terhadap Masa Studi

\begin{tabular}{lccc}
\hline Masa Studi & \multicolumn{2}{c}{ Asal Daerah $\left(\mathrm{X}_{3}\right)$} & Total \\
& Samarinda & Luar Samarinda & \\
\hline Masa Studi $\leq 4,8$ tahur & 27 & 39 & 66 \\
Masa Studi $>4,8$ tahur & 15 & 21 & 36 \\
\hline Total & 42 & 60 & 102 \\
\hline
\end{tabular}

Tabel 4. merupakan tabulasi silang program studi dengan masa studi mahasiswa FMIPA UNMUL.

Tabel 4. Tabulasi Silang Program Studi Terhadap Masa Studi

\begin{tabular}{|c|c|c|c|c|c|}
\hline \multirow[t]{2}{*}{ Masa Studi } & \multicolumn{4}{|c|}{ Program Studi $\left(\mathrm{X}_{4}\right)$} & \multirow[t]{2}{*}{ Total } \\
\hline & Statistika & Kimia & Fisika & Biologi & \\
\hline Masa Studi $\leq 4,8$ tahur & 24 & 33 & 4 & 5 & 66 \\
\hline Masa Studi $>4,8$ tahur & 7 & 0 & 6 & 23 & 36 \\
\hline Total & 31 & 33 & 10 & 28 & 102 \\
\hline
\end{tabular}

Tabel 5. merupakan tabulasi silang asal sekolah dengan masa studi mahasiswa FMIPA UNMUL.

Tabel 5. Tabulasi Silang Asal Sekolah Terhadap Masa Studi

\begin{tabular}{lccc}
\hline Masa Studi & \multicolumn{2}{c}{ Asal Sekolah $\left(\mathrm{X}_{5}\right)$} & Total \\
& SMA & SMK & \\
\hline Masa Studi $\leq 4,8$ tahun & 59 & 7 & 66 \\
Masa Studi $>4,8$ tahun & 31 & 5 & 36 \\
\hline Total & 90 & 12 & 102 \\
\hline
\end{tabular}

Tabel 6. merupakan tabulasi silang pekerjaan orang tua dengan masa studi mahasiswa FMIPA UNMUL.

Tabel 6. Tabulasi Silang Asal Sekolah Terhadap Masa Studi

\begin{tabular}{|c|c|c|c|c|c|}
\hline \multirow[t]{2}{*}{ Masa Studi } & \multicolumn{4}{|c|}{ Pekerjaan Orang Tua } & \multirow[t]{2}{*}{ Total } \\
\hline & PNS & PS & Wiraswasta & Lainnya & \\
\hline Masa Studi $\leq 4,8$ tahur & 17 & 24 & 11 & 14 & 66 \\
\hline Masa Studi $>4,8$ tahur & 11 & 11 & 7 & 7 & 36 \\
\hline Total & 28 & 35 & 18 & 21 & 102 \\
\hline
\end{tabular}




\subsection{Pembentukan Pohon Klasifikasi Dengan Menggunakan Algoritma C4.5}

Dalam proses pembentukan pohon klasifikasi, terhadap empat alur yaitu pemilihan variabel akar, penentuan cabang, kasus dibagi dalam cabang dan proses diulang sampai setiap cabang memiliki kelas yang sama. Pohon klasifikasi yang telah terbentuk akan memunculkan beberapa aturan (rule) sebanyak kelas yang terbentuk. Adapun data yang digunakan untuk proses pembentukan pohon klasifikasi ada 75 sampel, sedangkan 27 sampel sisanya untuk data testing pohon klasifikasi yang terbentuk.

Tahap pertama dalam pembentukan pohon klasifikasi adalah pemilihan node akar. Perhitungan untuk menentukan node akar menggunakan Persamaan (1) untuk menentukan nilai Gain dan Persamaan (2) untuk menentukan nilai Entropy.

Tabel 7. Hasil Perhitungan Gain dan Entropy untuk Node Akar

\begin{tabular}{|c|c|c|c|c|c|c|}
\hline Variabel & Kategori & Jumlah & $\begin{array}{l}\text { Masa } \\
\text { Studi } \\
\leq 4,8 \\
\text { tahun }\end{array}$ & $\begin{array}{l}\text { Masa } \\
\text { Studi } \\
>4,8 \\
\text { tahun }\end{array}$ & Entropy & Gain \\
\hline Total & & 75 & 43 & 32 & 0,9844 & \\
\hline \multirow[t]{4}{*}{ IPK } & & & & & & 0,1735 \\
\hline & $\geq 3,50$ & 29 & 22 & 7 & 0,7973 & \\
\hline & $3,00 \leq \mathrm{IPK}<3,50$ & 38 & 21 & 17 & 0,9919 & \\
\hline & $<3,00$ & 8 & 0 & 8 & 0 & \\
\hline Jenis & & & & & & 0,0049 \\
\hline \multirow[t]{2}{*}{ Kelamin } & Perempuan & 48 & 29 & 19 & 0,9684 & \\
\hline & Laki-laki & 27 & 14 & 13 & 0,9990 & \\
\hline Asal & & & & & & 0,0032 \\
\hline \multirow[t]{2}{*}{ Daerah } & Samarinda & 31 & 19 & 12 & 0,9629 & \\
\hline & $\begin{array}{l}\text { Luar } \\
\text { Samarinda }\end{array}$ & 44 & 24 & 20 & 0,9940 & \\
\hline Program & & & & & & 0,6499 \\
\hline \multirow[t]{4}{*}{ Studi } & Statistika & 23 & 17 & 6 & 0,8280 & \\
\hline & Kimia & 24 & 24 & 0 & 0 & \\
\hline & Fisika & 7 & 2 & 5 & 0,8631 & \\
\hline & Biologi & 21 & 0 & 21 & 0 & \\
\hline Asal & & & & & & 0,0001 \\
\hline \multirow[t]{2}{*}{ Sekolah } & SMA & 66 & 38 & 28 & 0,9833 & \\
\hline & SMK & 9 & 5 & 4 & 0,9910 & \\
\hline Pekerjaan & & & & & & 0,0097 \\
\hline Orang & PNS & 21 & 12 & 9 & 0,9852 & \\
\hline \multirow[t]{3}{*}{ Tua } & $\begin{array}{l}\text { Pegawai } \\
\text { Swasta }\end{array}$ & 27 & 17 & 10 & 0,9509 & \\
\hline & Wiraswasta & 13 & 6 & 7 & 0,9957 & \\
\hline & Lainnya & 14 & 8 & 6 & 0,9852 & \\
\hline
\end{tabular}


Perhitungan entropy dan gain dilakukan terus sampai setiap cabang memiliki kelasnya masing-masing. Maka terbentuk pohon klasifikasi sebagai berikut:

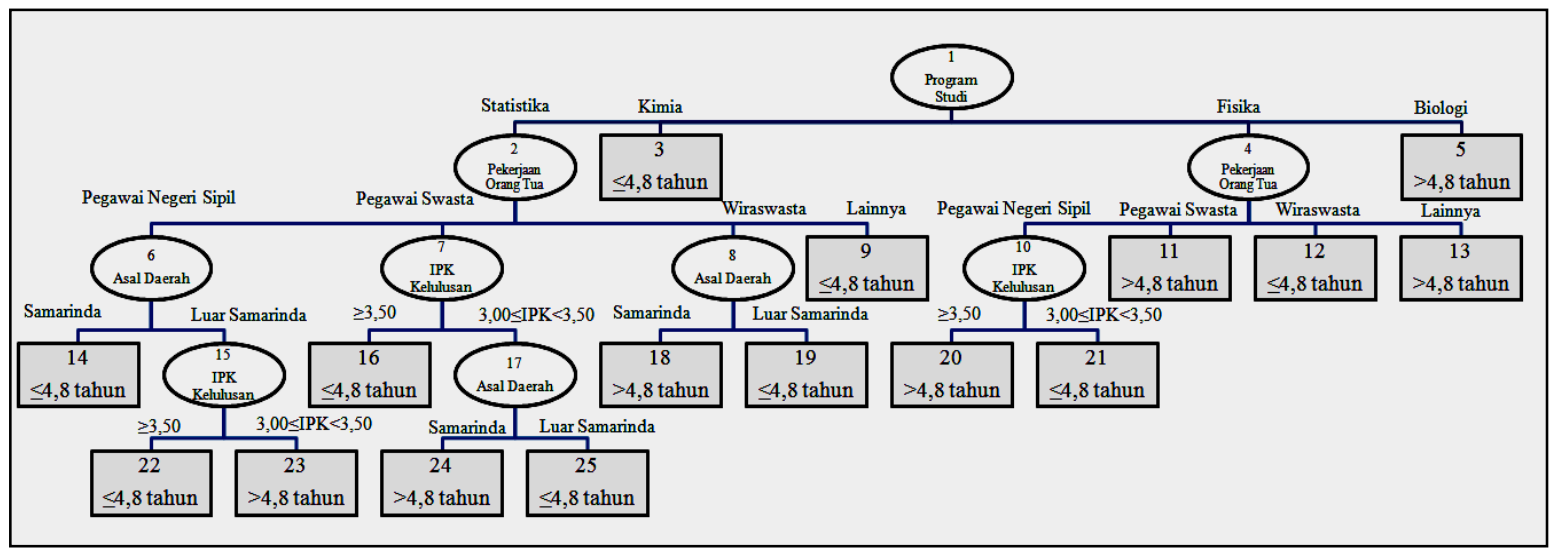

Gambar 2. Pohon Klasifikasi

Adapun bentuk aturan If dan Then untuk decision tree sebagai berikut:

a. Jika Program Studi = Statistika dan Pekerjaan Orang Tua $=$ PNS dan Asal Daerah $=$ Samarinda maka Masa Studi $\leq 4,8$ tahun

b. Jika Program Studi = Statistika dan Pekerjaan Orang Tua $=$ PNS dan Asal Daerah = Luar Samarinda dan IPK Kelulusan $\geq 3,50$ maka Masa Studi $\leq 4,8$ tahun

c. Jika Program Studi $=$ Statistika dan Pekerjaan Orang Tua $=$ PNS dan Asal Daerah = Luar Samarinda dan IPK Kelulusan 3,00 $\leq \mathrm{IPK}<3,50$ maka Masa Studi > 4,8 tahun

d. Jika Program Studi = Statistika dan Pekerjaan Orang Tua = Pegawai Swasta dan IPK Kelulusan $\geq 3,50$ maka Masa Studi $\leq 4,8$ tahun

e. Jika Program Studi = Statistika dan Pekerjaan Orang Tua = Pegawai Swasta dan IPK Kelulusan 3,00 $\leq$ IPK $<3,50$ dan Asal Daerah $=$ Samarinda maka Masa Studi > 4,8 tahun

f. Jika Program Studi = Statistika dan Pekerjaan Orang Tua = Pegawai Swasta dan IPK Kelulusan 3,00 $\leq$ IPK $<3,50$ dan Asal Daerah $=$ Luar Samarinda maka Masa Studi $\leq 4,8$ tahun

g. Jika Program Studi = Statistika dan Pekerjaan Orang Tua = Wiraswasta dan Asal Daerah $=$ Samarinda maka Masa Studi $>4,8$ tahun

h. Jika Program Studi = Statistika dan Pekerjaan Orang Tua $=$ Wiraswasta dan Asal
Daerah $=$ Luar Samarinda maka Masa Studi $\leq 4,8$ tahun

i. Jika Program Studi = Statistika dan Pekerjaan Orang Tua = Lainnya maka Masa Studi $\leq 4,8$ tahun

j. Jika Program Studi = Kimia maka Masa Studi $\leq 4,8$ tahun

k. Jika Program Studi = Fisika dan Pekerjaan Orang Tua = PNS dan IPK Kelulusan $\geq 3,50$ maka Masa Studi $>4,8$ tahun

1. Jika Program Studi $=$ Fisika dan Pekerjaan Orang Tua $=$ PNS dan IPK Kelulusan 3,00 $\leq$ IPK $<3,50$ maka Masa Studi $\leq 4,8$ tahun

m. Jika Program Studi $=$ Fisika dan Pekerjaan Orang Tua = Pegawai Swasta maka Masa Studi $>4,8$ tahun

n. Jika Program Studi = Fisika dan Pekerjaan Orang Tua $=$ WiraSwasta maka Masa Studi $\leq 4,8$ tahun

o. Jika Program Studi = Fisika dan Pekerjaan Orang Tua = Lainnya maka Masa Studi $>4,8$ tahun

p. Jika Program Studi = Biologi maka Masa Studi $>4,8$ tahun

\subsection{Uji akurasi Algoritma C4.5}

Untuk mendapatkan tingkat akurasi aplikasi dari hasil prediksi maka digunakan Persamaan (3). Setelah diperoleh hasil akurasi untuk jumlah data training 75 , dilakukan juga perhitungan analisis untuk jumlah data training 50 dan 25, sehingga diperoleh hasil seperti pada Tabel 8 .

Tabel 8. Hasil Akurasi Data Training dan Data Testing

\begin{tabular}{ccccccc}
\hline Jenis Data & \multicolumn{2}{c}{ Percobaan 1 } & \multicolumn{2}{c}{ Percobaan 2 } & \multicolumn{2}{c}{ Percobaan 3 } \\
& Data & Data & Data & Data & Data & Data \\
& Training & Testing & Training & Testing & Training & Testing \\
\hline Jumlah Data & 75 & 27 & 50 & 52 & 25 & 77 \\
Akurasi & $100 \%$ & $77,7 \%$ & $100 \%$ & $73 \%$ & $100 \%$ & $76,6 \%$ \\
\hline
\end{tabular}


Berdasarkan Tabel 4.14 menunjukkan bahwa untuk setiap data training pada setiap percobaan data memiliki tingkat akurasi 100 persen. Sementara itu untuk data testing yang memiliki tingkat akurasi tertinggi ada pada percobaan 1 dengan jumlah data testing 27 data yaitu 77,7 persen, sedangkan untuk data testing yang memiliki tingkat akurasi terendah ada pada percobaan 2 dengan jumlah data testing 52 data yaitu 73 persen.

\section{KESIMPULAN}

Berdasarkan hasil analisis dan pembahasan yang dilakukan, kesimpulan yang diperoleh dari penelitian mengenai masa studi mahasiswa FMIPA UNMUL yaitu:

1. Hasil pengklasifikasian masa studi mahasiswa Fakultas Matematika dan Ilmu Pengetahuan Alam Universitas Mulawarman angkatan 2008 dengan menggunakan metode Algoritma C4.5 didapat pohon klasifikasi dengan 16 aturan yang terbentuk.

2. Ketepatan hasil prediksi terhadap hasil pengklasifikasian masa studi mahasiswa Fakultas Matematika dan Ilmu Pengetahuan Alam Universitas Mulawarman angkatan 2008 untuk data training dengan jumlah 75 data didapat tingkat akurasi sebesar 100 persen dan data testing dengan jumlah data 27 didapat tingkat akurasi sebesar 77,7 persen.

\section{DAFTAR PUSTAKA}

[1]. David, N., 2015. Aplikasi Classification and Regresion Tree (CART) dan Regresi Logistik Ordinal dalam Bidang Ilmu Pendidikan dengan Studi Kasus Predikat Kelulusan Mahasiswa S1 Fakultas Matematika dan Ilmu Pengetahuan Alam Universitas Mulawarman. Skripsi, Prodi Statistika. Samarinda: FMIPA UNMUL.

[2]. David, H., 2014. Implementasi Data Mining dengan Algoritma C4.5 untuk Memprediksi Tingkat Kelulusan Mahasiswa. Jurnal yang dipublikasikan. Tangerang: Universitas Multimedia Nusantara Tangerang.

[3]. Efraim, Turban, J. E. Aronson., dan T. P. Liang, 2005. Decision Support Systems and Intelligent System. Yogyakarta : Andi Offset.

[4]. Kusrini, dan E. T. Luthfy, 2009. Algoritma Data Mining. Yogyakarta: Andi Offset.

[5]. Larose, 2005. Discovering Knowledge in Data: An Introduction to Data Mining. New Jersey : John Willey \& Sons.
[6]. Prasetyo, E., 2012. Data Mining : Konsep dan Aplikasi menggunakan Matlab. Yogyakarta : Andi Offset.

[7]. Quinlan J., 1986. “Introduction of Decision Tree”, Machine Learning, vol. 1, pp. 81-106.

[8]. Tan, P. N., M. Steinbach., dan V. Kumar, 2006. Introduction to Data Mining. New York : Pearson Education. 